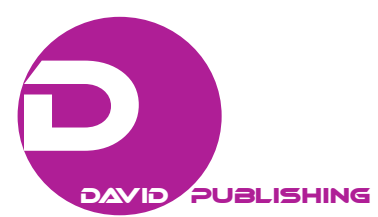

\title{
Analyzing the Roles of Agricultural Extension Agents in Hybrid Rice Technology Decision-Making Process of Farmers, Nay Pyi Taw, Myanmar
}

\author{
Naing Kyi Win, Kyaw Kyaw Win, Cho Cho San, Nyein Nyein Htwe \\ Yezin Agricultural University, Zeyarthiri Township, Nay Pyi Taw, Myanmar
}

\begin{abstract}
The study determined the roles of agricultural extension in hybrid rice technology decision-making process by extension agents, Nay Pyi Taw, Myanmar. The specific objectives were: to study personal characteristics of agricultural extension agents, experiences and their roles, to identify extension agents' opinion on hybrid rice technology decision-making process, and to determine relationship between the roles of agricultural extension agents and decision-making process of hybrid rice production. One hundred and eight extension agents were collected who were working in Department of Agriculture, Nay Pyi Taw area and surveyed and interviewed by questionnaires. The study revealed that majority of agricultural extension agents (65.7\%) were female staffs and most of extension agents (40.7\%) were under 30 years as young staffs. Majority of extension agents (81.5\%) were educated only Agri-Diploma. More than half (54.6\%) had one to five-year experiences in employment and 58.3\% had no hybrid rice training experience and source of information regarding the hybrid rice production was received 63.9\% from Department of Agriculture (DOA). Study found that there was highly significant relationship between most of the roles of agricultural extension agents and hybrid rice technology decision-making process of stages 4 and 5. And then most of the extension agents' roles singnificantly related with stage 2 except role of conducting introduction of hybrid seeds and distribution through by Seed Co. Ltds which was highly significant. Beside, most of the roles of extension agents significantly related with stage 3. However stages 1 and 6 were no singnificantly related. Finally above all, a well structure seed business, Good Agricultural Practices and farm level mechanization and quality extension service are very important to increase the adoption of hybrid rice in Myanmar.
\end{abstract}

Keywords: agricultural extension agents’ roles, hybrid rice, decision-making process

\section{Introduction}

The role of agricultural extension in national agricultural development is pertinent. It has been established

\footnotetext{
Acknowledgements: Thanks to Department of Agriculture Nay Pyi Taw Council Area, particularly extension agents from respective townships who were working in the field level and admin-staffs. And deserve our sincere appreciation for devoting their time to participating in the field interviews, without them the study would not have been possible.

Naing Kyi Win, Ph.D. student, Department of Agronomy, Yezin agricultural University, Nay Pyi Taw, Myanmar.

Kyaw Kyaw Win, professor and head, Dr., Department of Agronomy, Yezin agricultural University, Nay Pyi Taw, Myanmar.

Cho Cho San, professor and head, Dr., Department of Agricultral Economics, Yezin Agricultural University, Nay Pyi Taw, Myanmar.

Nyein Nyein Htwe, head, Dr., Department of Agricultural Extension, Yezin Agricultural University, Nay Pyi Taw, Myanmar.

Correspondence concerning this article should be addressed to Naing Kyi Win, Department of Agricultural Research, Zeyarthiri Township, Nay Pyi Taw 15013, Myanmar.
} 
that no nation will have real growth in the agricultural sector without effective extension service. Many countries had achieved food security as a result of technology transfer for food crops and farmer capacity building in proper use of natural resources and were facilitated by agricultural extension (Swanson \& Rajalahti, 2010).

The agricultural sector is the biggest contributor to the growth of the national economy, the government plays agricultural development at the center of its efforts to build a modern industrialized Myanmar. The agriculture sector of Myanmar contributes 28.6\% to GDP and 25.5\% to export earnings, and employs 61.2\% of labor force (MoALI, 2016). In Myanmar total rice growing area was 17.69 million acres (7.16 million hectare), around 1,300 million baskets (26.73 million Mt) of production and 75.49 baskets of yield per acre (3.9 Mt per ha), in 2016-2017 growing season (Rice Division, DOA, 2017). In Myanmar, there are four groups of rice variety: high yielding variety (HYV), high quality variety (HQV), hybrid variety (HV), and traditional variety. From that on, rice yields and farmers' income would be increased by altering production of hybrid rice, consequently results are alleviating of poverty and better living standard of Myanmar farmers (DOA, 2015). Hybrid varieties have shown 15-20\% higher yield potential than inbred rice varieties under farmers' field conditions. It has resistant to drought and salinity however needs to buy seed every season (IRRI, 1991). It could be successful 200 baskets (potential yield) per acre if had systematic and proper care. Within the last five years, around 3\% out of total hybrid rice growing areas about over 17 million acres in the whole Myanmar both raining and summer rice growing season have grown. And then gradually, it has declined due to becoming low government intervention. To get superior output production due to the variety change, hybrid rice has the special characteristics such adaptable for local condition, unusual productivity, eating good quality, and better grinding quality when comparing with exemplary rice varieties as Sin Thu Kha, Manawthukha, A Yar Min, and Thee Htet Yin (DOA, 2015).

Agricultural extension division of the Department of Agriculture (DOA) under the Ministry of Agriculture, Livestock and Irrigation is taking part its main task of transferring technologies to the farmers for getting better economic return by increasing yield per acre and improving crop quality. Under DOA, there is "Agricultural Extension Division” which has 9,414 staffs out of 14,774 staffs in DOA. Out of 9,414 which 7,516 are agricultural extension staffs including 6 Ph.D., 25 M.Sc. and 1,680 B.Agr.Sc. and diploma holders. Its major function is transferring appropriate technologies from different resources on the status of farmers. And it also organizes and motivates farmers to adopt proven technologies for better livelihood in rural farming community and increase national agricultural production (Khaing, 2017). Nowadays, DOA is leading to producing the marketable crops which are nutritious and safety. In doing these activities, it conducts the technology transfer by organizing the farmer seed grower association, building the modern villages which used the integrated advanced technology. Implementing this activity, it widely conducts by organizing as the public-private partnership. Moreover, to reach the advanced agricultural technology, information concerned with the climate and market to the farmers in time, it carries out the education programs through the media. On the other side, with the aims of the farmers to use the quality agricultural inputs in line with the rules and regulations, it directly conducts in the fields (AED, 2017).

This study was a part of the research conduct and analyzing the the roles of extension agents which change the attitudes of farmers (beliefs, behaviors, and intervention factors) and decision-making process affecting to utilize the hybrid rice technology. In addition, to building a decision skill of farmers to adopt the new technology, hybrid rice among the Nay Pyi Taw rice farmers is educated by using the extension activities which need to be modified. 
Study objectives:

(1) To study personal characteristics of agricultural extension agents, experiences, and their roles;

(2) To identify extension agents' opinion on hybrid rice technology decision-making process;

(3) To determine relationship between the roles of agricultural extension agents and decision-making process of hybrid rice production.

\section{Literature Review}

Scarce resources for agricultural production and unfavorable conditions will make it hard to meet future demand in rice and threaten future food security. Hybrid rice technology is a method to increase the productivity of resources needed for rice production. Hybrid rice is the first or second generation derived from a cross between two genetically different parents. The goal is to find a hybrid rice seed that has certain advantages such as higher yields. Hybrid rice can be produced from either japonica or indica varieties. Since rice plants are naturally self-pollinating, i.e. male and female at the same time, and since the breeding of hybrid rice requires control of pollination, one parent line needs to be male sterile. This line does not have viable pollen and is therefore referred to as female and accepts pollen from other rice plants. The other parent line is the male parent line, which is a normal pollen producing parent. There are currently two different methods commercially used to create hybrid rice: a three-line system and a two-line system (Ludwig, 2012). Agricultural extension has played a role in helping to achieve a variety of agricultural development goals (Davis, 2008). Agricultural extension work is a significant social innovation and important force in agricultural change, which has been created and recreated, adapted and developed over the century (Gwyn \& Garforth, 1998). The role of an agricultural extension agents helps farmers from sound opinions and make good decisions by communicating with them and providing them with information they need. Opinions and decisions also are based on farmers' values, although, they are not always clear about this relationship, extension also must help them clarify it. Hence the agents can help farmers with their decision-making on their pathway towards knowledge as well as on their path way toward choice (Van den Ben \& Hawkins, 1996).

The innovation decision process is the process through which an individual (or other decision-making unit) passes (1) from first knowledge of an innovation, (2) forming an attitude toward the innovation, (3) to a decision or adopt or reject, (4) to implementation of the new idea, (5) to confirmation of this decision. This process consists a series of action and choices over time through an individual (or organization) who evaluates the new idea and decides whether or not to incorporate the innovation into ongoing practices (Roger, 1995).

Myanmar agricultural extension has continuously practiced the traditional extension approach, particularly more on individual contact. This approach has been relying on "progressive farmers" who are generally easiest to reach and have access to sufficient resources land, labor, physical and human capital. It was expected that the adoption of technology by progress farmers would have a trickledown effect on majority of farmers (Oo \& Ando, 2012). Hybrid rice program which started since 2011-2012 growing season and government aims to change the varieties like hybrid rice and participate in hybrid rice seed production with private sectors and encourage farmers to have priority in Nay Pyi Taw area and wide spread to nation. At that time extension methodologies which they used by individual, group and mass media methods widely made campaigns in timely manner. In this context, agricultural extension agents applied nine roles as conducting introduction of hybrid seeds and distribution by Seed Co. Ltds, linking input dealers to get the fertilizers and chemicals, supporting farmers with service providers to get farm machinery in time for land preparation, harvesting and 
labors for transplanting, connecting between private sector and farmers to do the contract farming, providing market access and price information, accessing credit organizations for investment, conducting the individual contact to promote awareness and adoption of hybrid rice, and conducting meeting, training, demonstration and field days to sensitize farmers, and disseminating information with technology (ICT) such as news paper, radio, television, leaflets, and posters. The conceptual framework, relationship between roles of agricultural extension agents and technology decision-making process is shown in Figure 1.

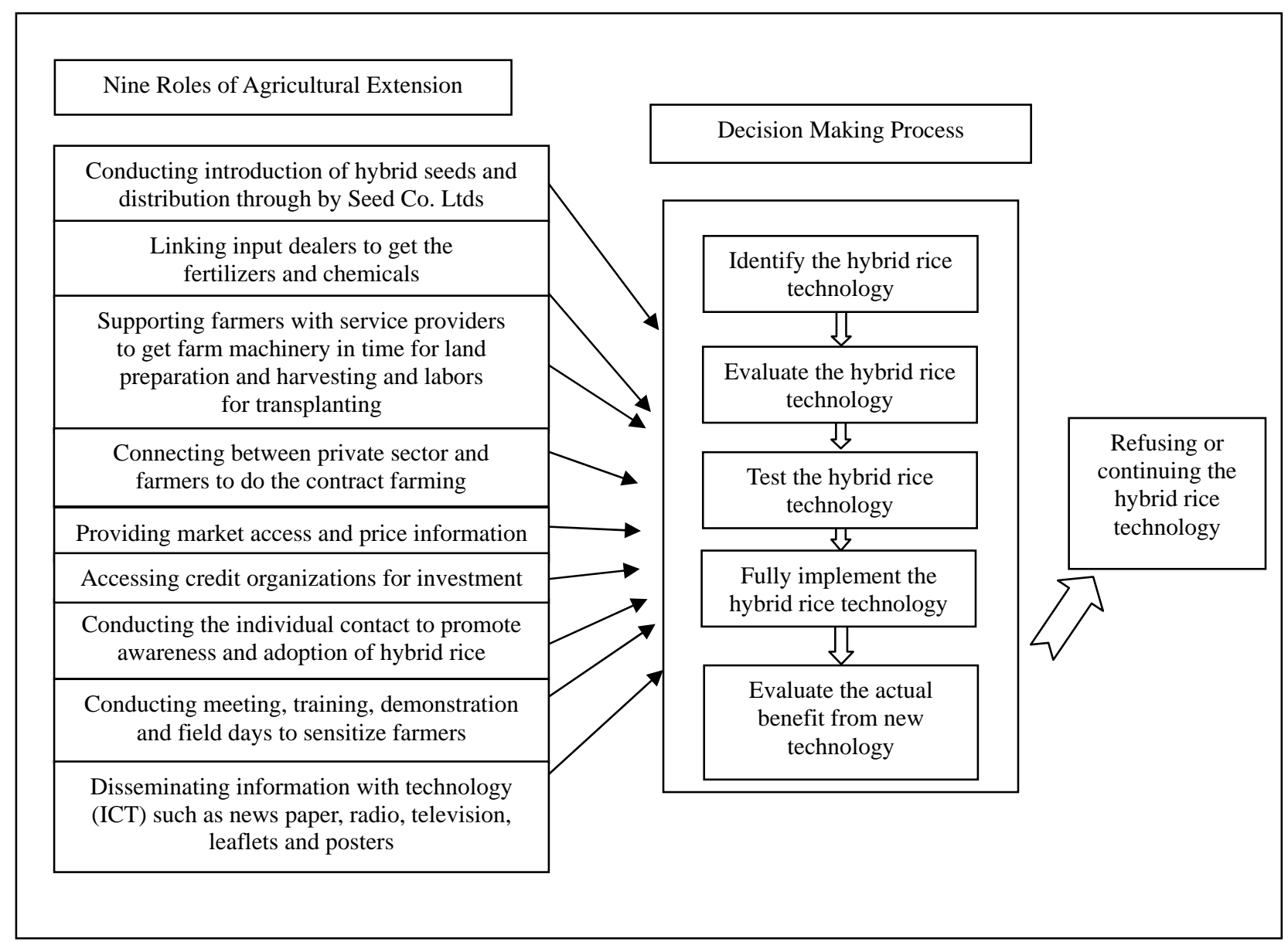

Figure 1. Conceptual framework.

\section{Study Area}

Net sown acres of 286,360 including 169,166 acres in Nay Pyi Taw area were paddy growing areas, in which 99,331 farm families were participating in agriculture. Farmers have been growing rice as local, high yield and hybrid and average yield was 87.10 baskets per acre, in 2016-2017 growing year. It has 249 agricultural extension staffs, 18 frontier education camps, and 40 agricultural knowledge centers. Therefore, it can be calculated as agricultural extension agents and farm families' ratio is 1:400 generally (DOA, 2016-2017). In addition, few NGO, INGO and private inputs Co. Ltds extension workers who were educating non-formal education to farmers. They apply the extension strategy which is conventional and very little participatory approach. Extension agents mostly use meeting, demonstration, field days, distribution of leaflets and pamphlets and broadcast by farmer channel media. The survey was conducted in Nay Pyi Taw area which has private hybrid rice seed production Co. Ltds and started hybrid rice cultivation. 


\section{Methodology}

This study used survey and interview research design using open and closed questionaries. The population of the research was 249 extension agents who worked in agricultural extension activities (DOA, 2016). This research mainly selected sample based on supervision of hybrid rice growing farmers and the sample size was 108 respondents including 17 admin staffs and 91 field level staffs. There were included headquarters level and districts and townships level and field level extension agents. Data were collected by using questionnaire and interviewing the 108 extension agents conducted in August to November, 2017. Descriptive statistics were used to describe personnel characteristics of extension agents and experience on hybrid rice and their roles on hybrid rice production. For inferential statistic, Chi-squire was employed to determine between independent variables and dependent variables. This study was analyzed by statistical package for social science (SPSS) ver. 16.

\section{Results and Discussion}

\section{General Attitudes of Extension Agents to Hybrid Rice Production}

Extension agents positively accepted that hybrid rice has more yield advantage than HYV varieties due to the hybrid vigor associated with hybrid rice. Hybrid rice can be grown three times per year because it has shorter duration and greater shock resistances than that with local rice varieties and increase more yield, more income and impact of hybrid rice on food security aspects. They also agreed the social and economic impact feasibility growing hybrid rice. On the other hand, the impacts of technologies were applying the more pesticides and chemical fertilizers which were negative effect to environment. Another crucial disadvantage of hybrid rice is that its produced grain cannot be used as seed for the next season and had inferior quality and competitive market and price compared to local varieties. At the farm level, adoption of hybrid rice might present excessive financial or management constraints due to higher seed costs and different agricultural techniques that are needed. As a positive effect to hybrid rice, government intervention played a major role for diffusion of hybrid rice. Despite its high-yielding characteristic and its tendency for better adaptability to biotic and abiotic stress, adoption of hybrid rice has been delayed.

\section{Personnel Characteristics of Agricultural Extension Agents and Their Experiences}

Study resulted that more than half of agricultural extension agents (65.7\%) were female staffs. Most of extension agents (40.7\%) were under 30 years. Majority of extension agents (81.5\%) were educated only Agri-Diploma. More than half (54.6\%) had one to five-year experiences in employment, 58.3\% had no hybrid rice training exposure and source of information regarding the hybrid rice production received $63.3 \%$ from DOA, 29.6\% from DAR, 26.9\% from IRRI, 17.6\% from internet and 14.8\% from YAU respectively (Table 1). This study indicated that the main difficulties identified by extension agents regarding technical services providing to farmers were lack of resources, poor knowledge regarding hybrid rice technology, illiteracy among the farmers and communication problems. The most appropriate teaching methods identified by extension agents were demonstration, formal group meetings, and field days. The most frequently methods used by extension agents were farmers meeting and individual contact. The extension agents identified that they need training in improved crop managements, extension managements. Senior extension staffs were their main sources of information of the extension agents. The major difficulties faced by the field assistants were non availability of their office's number of extension workers who had very small, low qualification and 
communication skill which need to be improved, similarly pointed out by Farooq, Ishaq, Shah, and Karim (2010).

Table 1

Personal Characteristics Experiences and Source of Information

\begin{tabular}{|c|c|c|}
\hline Personal characters and experiences & Number & Percent \\
\hline \multicolumn{3}{|l|}{ Gender } \\
\hline Male & 37 & 34.3 \\
\hline Female & 71 & 65.7 \\
\hline \multicolumn{3}{|l|}{ Age } \\
\hline Under 30 & 44 & 40.7 \\
\hline $33-40$ & 34 & 31.5 \\
\hline $41-50$ & 14 & 13.0 \\
\hline 51-60 $(\max .=56, \min .=25$, average = 14.5) & 16 & 14.8 \\
\hline \multicolumn{3}{|l|}{ Education } \\
\hline Agri-high school & 3 & 2.8 \\
\hline Agri-Diploma & 88 & 81.5 \\
\hline B.Agr.Sc. & 15 & 13.9 \\
\hline M.Agr.Sc. & 1 & 0.9 \\
\hline Ph.D. & 1 & 0.9 \\
\hline \multicolumn{3}{|l|}{ Year of employment } \\
\hline $1-5$ & 59 & 54.6 \\
\hline $6-10$ & 11 & 10.2 \\
\hline $11-20$ & 16 & 14.8 \\
\hline $21-30$ & 15 & 13.9 \\
\hline Above 30 & 7 & 6.5 \\
\hline \multicolumn{3}{|l|}{ Training experiences } \\
\hline No training of hybrid rice & 63 & 58.3 \\
\hline One time & 28 & 25.9 \\
\hline Two times & 10 & 9.3 \\
\hline Three times & 6 & 5.6 \\
\hline Four times & 1 & 0.9 \\
\hline \multicolumn{3}{|l|}{ Source of information for extension agents } \\
\hline \multicolumn{3}{|l|}{ Department of Agricultural Research (DAR) } \\
\hline Yes & 32 & 29.6 \\
\hline No & 76 & 70.4 \\
\hline \multicolumn{3}{|l|}{ Internet } \\
\hline Yes & 19 & 17.6 \\
\hline No & 89 & 82.4 \\
\hline \multicolumn{3}{|l|}{ International rice research institute (IRRI) } \\
\hline Yes & 29 & 26.9 \\
\hline No & 79 & 73.1 \\
\hline \multicolumn{3}{|l|}{ Yezin Agricultural University (YAU) } \\
\hline Yes & 16 & 14.8 \\
\hline No & 92 & 85.2 \\
\hline \multicolumn{3}{|l|}{ Department of Agriculture (DOA) } \\
\hline Yes & 69 & 63.9 \\
\hline No & 39 & 36.1 \\
\hline
\end{tabular}




\section{Agricultural Extension Agents’ Roles on Hybrid Rice Production}

The study revealed that majority (74.1\%) extension agents persuaded "conducting introduction of hybrid seed and distribution through seed Co. Ltds" seasonally and 62\% of agents served "linking between input dealers and farmers used the fertilizers and chemicals" as much as possible.

And then $50.9 \%$ of agents showed the role of "supporting farmers with service providers to get farm machinery in time for land preparation and harvesting and labors for transplanting” and 54.6\% of agents interacted "connecting to private sector and farmers to do the contract farming". Besides, $55.6 \%$ of agents supported "providing market access and price information" as rice collectors to buy the rice from farmers and shared the markets information and 52.8\% of agents assisted "accessing credit organizations" to get credit. Moreover, majority (84.3\%) extension agents applied "conducting the individual contact to promote awareness and adoption of hybrid rice production" and $82.4 \%$ of extension agents educated to farmers "conducting meeting, training, demonstration and field days to sensitize farmers" and $73.8 \%$ of agents tried to arouse "disseminating information with technology (ICT) such as news paper, radio, television, leaflets and posters". The success of extension services depends on the role of extension officers to transfer technology and technical competence in developing farmers to increase their productivity (Rahim, 2008). This study pointed out that role of extension agents as change agents is divided into four which encompasses role as catalyst, resource linker, solution giver, and process helper. Based on above finding, there were a wide variety of views on extension agent's roles (Table 2) which were also supported by Rahim (2008).

Table 2

Roles of Agricultural Extension Agents

\begin{tabular}{|c|c|c|c|c|}
\hline \multirow{2}{*}{ Roles of extension agents } & \multicolumn{2}{|c|}{ Supported } & \multicolumn{2}{|c|}{ No supported } \\
\hline & No. & $\%$ & No. & $\%$ \\
\hline Conducting introduction of hybrid seeds and distribution through by Seed Co. Ltds. & 80 & 74.1 & 28 & 25.9 \\
\hline Linking input dealers to get the fertilizers and chemicals. & 67 & 62.0 & 41 & 38.0 \\
\hline $\begin{array}{l}\text { Supporting farmers with service providers to get farm machinery in time for land } \\
\text { preparation and harvesting and labors for transplanting. }\end{array}$ & 55 & 50.9 & 53 & 49.1 \\
\hline Connecting between private sector and farmers to do the contract farming. & 59 & 54.6 & 49 & 45.4 \\
\hline Providing market access and price information. & 60 & 55.6 & 48 & 44.4 \\
\hline Accessing credit organizations for investment. & 57 & 52.8 & 51 & 47.2 \\
\hline $\begin{array}{l}\text { Conducting the individual contact to promote awareness and adoption of hybrid rice } \\
\text { production. }\end{array}$ & 91 & 84.3 & 17 & 15.7 \\
\hline Conducting meeting, training, demonstration, and field days to sensitize farmers. & 89 & 82.4 & 19 & 17.6 \\
\hline $\begin{array}{l}\text { Disseminating information with technology (ICT) such as newspaper, radio, television, } \\
\text { leaflets, and posters. }\end{array}$ & 80 & 74.1 & 28 & 25.9 \\
\hline
\end{tabular}

\section{Extension Agents’ Opinion on Hybrid Rice Technology Decision-Making Process}

This research revealed that all respondents agreed hybrid rice decision-making process diagram flow of farmers and also stage 1 and stage 6 were not constrained for them. Extension agents had explained stage 1, farmers could clearly identify hybrid rice technologies which were educated by using ICT material and upon the stage 6, farmers weighed the positive and negative benefit and consequences and favored the positive outcomes. And then $61.1 \%$ of agents showed stage 2 which was not important. In this step, the baseline criteria for judging the hybrid rice technology were set up, for consideration of cost and benefit by supporting the best source information. Extension agents educated to farmers "conducting meeting, training, demonstration and 
field days to sensitize farmers”. And also the same resulted that $88.8 \%$ of the agents answered stage 3 which was also not important because of supporting the seed to farmers from government subsidy program for testing. Study pointed out that more than half $58.3 \%$ of agents felt the fourth stage which also was not important because government encouraged farmers to grow and granted them to buy the product. However, more than half $53.7 \%$ of the agents pointed out that the fifth step was important for them (Table 3).

Table 3

Extension Agents’ Opinion on Hybrid Rice Technology Decision-Making Process

\begin{tabular}{lllll}
\hline \multirow{2}{*}{ Statement of the decision-making process } & \multicolumn{2}{c}{ Important stage } & \multicolumn{2}{c}{ Not important stage } \\
\cline { 2 - 5 } & No. & $\%$ & No. & 100 \\
\hline Identify the hybrid rice technology & 0 & 0 & 108 & 61.1 \\
Evaluate the hybrid rice technology & 42 & 38.9 & 66 & 88.9 \\
Test the hybrid rice technology & 12 & 11.1 & 96 & 58.3 \\
Fully employment the hybrid rice technology & 45 & 41.7 & 63 & 46.3 \\
Evaluate actual benefit of hybrid rice technology & 58 & 53.7 & 50 & 108 \\
Refuse or accept continuously the hybrid rice technology & 0 & 0 & 100 \\
\hline
\end{tabular}

Due to the fact that profit is one of the main concerns in every decision-making process, farmers used the judgment principles and decision-making criteria to evaluate. In this step, experience and effectiveness of the judgment principles come into play. Farmers compared with HYV varieties and hybrid rice for their profits and risks.

\section{Relationship Between the Roles of Agricultural Extension Agents and Hybrid Technology Decision-Making Process}

This finding revealed that there were no significantly relationships between roles of extension agents against to stage 1 and stage 6 . However Chi-squire test statistic raveled that stage 2 was related to extension agents' roles as conducting introduction of hybrid seeds and distribution through by Seed Co. Ltds was highly significant. And linking input dealers to get the fertilizers and chemicals, accessing credit organizations for investment, individual and group contact and information technology were significantly related. Stage 3 was high significant with extension agent's roles as connecting between private sector and farmers to do the contract farming. Besides conducting introduction of hybrid seeds and distribution, linking input dealers, supporting farmers with service providers, providing market access and price information, and accessing credit organizations for investment were significantly related. Stage 4 was highly significant with extension agents' roles as conducting introduction of hybrid seeds and distribution through by Seed Co. Ltds, linking input dealers to get the fertilizers and chemicals, supporting farmers with service providers to get farm machinery in time for land preparation and harvesting and labors for transplanting, connecting between private sector and farmers to do the contract farming, providing market access and price information, accessing credit organizations for investment. Moreover, conducting the individual contact to promote awareness and adoption of hybrid rice production, conducting meeting, training, demonstration and field days to sensitize farmers were significantly related. In addition, stage 5 was highly significant to extension agents' roles as conducting introduction of hybrid seeds and distribution through by Seed Co. Ltds, linking input dealers to get the fertilizers and chemicals, connecting between private sector and farmers to do the contract farming, providing market access and price information and accessing credit organizations for investment. Lastly, supporting farmers with service providers to get farm machinery in time for land preparation and harvesting and labors for 
transplanting, conducting the individual contact to promote awareness and adoption of hybrid rice production and conducting meeting, training, demonstration and field days to sensitize farmers were related significantly (Table 4).

Research results highlighted the roles of extension agents facilitated in hybrid rice decision-making process of farmers which were insufficiently effective to adopt the hybrid rice production. Among them, research results pointed out that it had constraint to overcome the stages 4 and 5 for extension agents. Farm families have to make a number of different types of decisions, because they face different kinds of problems. Each type requires its own kind of support from agricultural extension. To be able to make good decisions, farmers need information which comes from different sources. They may also need to help to integrate this information, especially when it is conflicting. A problem is that government extension may not be quite competent to provide and not evaluate information on factors influencing market prices, such as quality requirements. The extension agents can give the farmer a recommendation regarding which decision to make or he can guide him with the decision making process (van den Ban, 1988). Pervez, Gao, Zeng, and Uddin (2016) similarly indicated that Chinese hybrid farmers are getting benefit from ICT as e-commerce and internet use and farmers' co-operatives provide a wide range of information on government subsidies, rice cultivation technologies, market information and many other issues which reduce the social and natural risks in agricultural production. Large numbers of public-private partnership (PPP) activities are providing their advisory services at country level and input supports. Creating a positive attitude towards hybrid rice has a significant economic impact on its adoption and also the mass media in the promotion of hybrid rice technology.

Table 4

Relationship Between the Roles of Extension Agents and Hybrid Rice Technology Decision-Making Process

\begin{tabular}{|c|c|c|c|c|c|c|}
\hline \multirow{3}{*}{ Roles of agricultural extension agents } & \multicolumn{6}{|c|}{ Hybrid technology decision-making process } \\
\hline & Stage (1) & Stage (2) & Stage (3) & Stage (4) & Stage (5) & Stage (6) \\
\hline & $\begin{array}{l}\text { Identify the } \\
\text { technology }\end{array}$ & $\begin{array}{l}\text { Evaluate the } \\
\text { technology }\end{array}$ & $\begin{array}{l}\text { Test the } \\
\text { technology }\end{array}$ & $\begin{array}{l}\text { Full } \\
\text { implement }\end{array}$ & $\begin{array}{l}\text { Evaluate } \\
\text { actual } \\
\text { benefit }\end{array}$ & $\begin{array}{l}\text { Refuse or } \\
\text { accept } \\
\text { continuously }\end{array}$ \\
\hline $\begin{array}{l}\text { Conducting introduction of hybrid seeds and } \\
\text { distribution through by Seed Co. Ltds. }\end{array}$ & - & $16.030 * * *$ & $4.790^{*}$ & $35.265 * * *$ & $38.210 * * *$ & - \\
\hline $\begin{array}{l}\text { Linking input dealers to get the fertilizers and } \\
\text { chemicals. }\end{array}$ & - & $7.978^{*}$ & $8.396^{*}$ & $26.987 * * *$ & $26.800 * * *$ & - \\
\hline $\begin{array}{l}\text { Supporting farmers with service providers to get } \\
\text { farm machinery in time for land preparation and } \\
\text { harvesting and labors for transplanting. }\end{array}$ & - & 3.315 & $9.177^{*}$ & $12.120 * * *$ & $8.300^{*}$ & - \\
\hline $\begin{array}{l}\text { Connecting between private sector and farmers to } \\
\text { do the contract farming. }\end{array}$ & - & 2.588 & $11.419 * *$ & $11.324 * * *$ & $10.388 * * *$ & - \\
\hline Providing market access and price information. & - & 7.013 & $9.290^{*}$ & $15.427 * * *$ & $14.420 * * *$ & - \\
\hline Accessing credit organizations for investment. & - & $5.319 *$ & $5.206 *$ & $14.531 * * *$ & $16.127 * * *$ & - \\
\hline $\begin{array}{l}\text { Conducting the individual contact to promote } \\
\text { awareness and adoption of hybrid rice production. }\end{array}$ & - & $6.246^{*}$ & 0.310 & $6.942^{*}$ & $10.550 *$ & \\
\hline $\begin{array}{l}\text { Conducting meeting, training, demonstration, and } \\
\text { field days to sensitize farmers. }\end{array}$ & - & $5.177^{*}$ & 0.000 & $6.790^{*}$ & $9.886^{*}$ & \\
\hline $\begin{array}{l}\text { Disseminating information with technology (ICT) } \\
\text { such as newspaper, radio, television, leaflets, and } \\
\text { posters. }\end{array}$ & - & $5.053 *$ & 0.344 & 3.542 & 7.427 & \\
\hline
\end{tabular}

Notes. * Significance level at $0.05 ; * *$ significance level at $0.01 ; * * *$ significance level at 0.001 . 


\section{Conclusion and Recommendations}

This research indicated that most of agricultural extension agents were young and low-experience to extension strategy and methodology and also hybrid rice technology. Sources of information of new technology for extension agents who come down from Department of Agriculture mostly and were supported to farmers by their roles to adopt the hybrid rice technology depend on top down guidelines. On the other hand, they were not to overcome the stages 4 and 5 among the farmers' decision-making to hybrid rice technology. In addition, they mentioned the need of the stable market and farmers wanted to get higher rice price than other varieties repeatedly.

Recommendations were presented as follows:

(1) There should be practiced by doing both extension and technical training to more understand the appropriate extension strategies and methodologies and communication channels.

(2) Extension approach should be changed from conventional to project extension approach with private sector participation and needs to be sustainable after project.

(3) Government should formulate the extension policy in accordance with the requirements of extension agents, farmers, researchers, and private extension workers to be combined approaches.

Finally, above all a well structure seed business and stable market, Good Agricultural Practices, and farm level mechanization and quality extension service are very important to increase the adoption of hybrid rice in Myanmar.

\section{References}

AED (Agricultural Extension Division). (2017). Annual report of statistic year book. Department of Agriculture, Ministry of Agriculture, Livestock and Irrigation, Myanmar.

Davis, K. E. (2008). Extension in sub-Saharan Africa: Overview and assessment of past and current models, and future prospects. Journal of International Agricultural and Extension Education, 15(3), 15-28.

DOA (Department of Agriculture). (2015). Hybrid rice. Unpublished report, Nay Pyi Taw, Myanmar.

DOA (Department of Agriculture), Nay Pyi Taw area. (2016-2017). Crop statistical year report. Unpublished report, Nay Pyi Taw, Myanmar.

Farooq, A., Ishaq, M., Shah, N., \& Karim, R. (2010). Agricultural extension agents and challenges for sustainable development (a case study of oeshawar valley), Pakistan. Sarhad J. Agric., 26(3).

Gwyn, E. J., \& Garforth, C. (1998). The history, development, and future of the agricultural extension, improving agricultural extension. A Reference Manual.

IRRI (International Rice Research Institutes). (1991). Hybrid rice breeding manual HR2-01-1991. Los Baños, Laguna, Philippines.

Khaing, A. A. (2017). Agricutlutral extension history in Myanmar, "strengthening institutional capacity, extension services and rural livelihoods in the Central Dry Zone and Ayeyarwaddy Delta Region of Myanmar”. ACIAR project (ASEM-2011-043).

Ludwig, T. (2012). Impact of hybrid rice on food security: A spatial equilibrium analysis of global adoption and diffusion of hybrid rice varieties. Theses and Dissertations, 444.

MOLAI (Ministry of Agricultural, Livestock and Irrigation). (2016). Myanmar agriculture sector in brief 2016. Ministry of Agricultural, Livestock and Irrigation, Nay Pyi Taw, Myanmar.

Oo, K., and Ando, K. (2012). Improving Myanmar agricultural services. Empirical Study View and Perception Field Extension Agents in Mandalay Division Myanmar. Kyoto Working Paper on Area Studies No 123 (G-COE Series 121) January 2012.

Pervez, A. K. M., Gao, Q., Zeng, Y., \& Uddin, M. (2016). Hybrid rice: Bangladesh's failure and China's success. Journal of Agriculture and Ecology Research International.

Rahim, M. S. (2008). Kompetensi dan Amalan Pendidikan Pengembangan (Concept and Practice of Extension Education). Buletin Pengembangan (Extension Bulletin), Bil. 1, University Putra Malaysia.

Roger, E. M. (1995). Diffusion of innovation (4th ed.). New York, London, Toronto, Sydney, Singapore: Free Press. 
Rice Division. (2017). Annual report of statistic year book. Department of Agriculture, Ministry of Agriculture, Livestock and Irrigation, Myanmar.

Swanson, B. E., \& Rajalahti, R. (2010). Strengthening agricultural extension and advisory systems. The World Bank, Discussion Paper 45.

Van den Ban, A. W. (1988). Supporting farmer, decision making by agricultural extension. Journal of Extension Systems, $14,5-67$. Van den Ban, A. W., \& Hawkins, H. S. (1988). Agricultural extension (1st ed.). Avon, Great Britain: Bath Press.

Van den Ban, A. W, \& Hawkins, H. S. (1996). Agricultural extension (2nd ed.). Blackwell Science. 